\title{
Government Funding Mechanism Code
}

National Cancer Institute

\section{Source}

National Cancer Institute. Government Funding Mechanism Code. NCI Thesaurus. Code C93838.

A coded value specifying the unique identifier for areas of extramural research activity applied to various funding mechanisms. 